\title{
Understanding The Dynamic of International System Through The Lens of Complex System Approach
}

\author{
Indra Kusumawardhana \\ Universitas Pertamina
}

\begin{abstract}
The International Relations Study has undergone many changes in its dynamics, especially in view of the dynamic conditions of world politics. It directly influences the development of the IR study. This paper discusses how the theory of complex systems explain the dynamics of the international system after the end of the Cold War. Through the theory, the author seeks to see the changes that occur in interstate interaction, especially in the framework of thinking about the interests of each country. Interaction between countries then encourage the existence of different systems between one another, depending on how the country chooses interaction groups. The author also seeks the inter-state interaction that formed into an international system can be studied from the transition process to change the direction of interaction to see how the true international system is formed through the views of the theory of complex systems.
\end{abstract}

Keywords: International Relations, International System, Complex System Theory

Kajian Hubungan Internasional sudah mengalami banyak perubahan di dalam dinamikanya, terutama melihat kondisi perpolitikan dunia yang dinamis. Hal ini memberikan pengaruh ke dalam perkembangan keilmuan Hubungan Internasional. Tulisan ini membahas mengenai bagaimana teori sistem kompleks menjelaskan dinamika sistem internasional setelah Perang Dingin berakhir. Melalui teori tersebut, penulis berupaya melihat perubahan yang terjadi di dalam interaksi antar negara, terutama dalam kerangka pemikiran mengenai kepentingan negara. Interaksi antar negara tersebut kemudian mendorong adanya sistem yang berbeda antara satu dengan yang lain, tergantung pada bagaimana negara memilih kelompok interaksinya. Penulis juga berpandangan bahwa interaksi yang terbentuk menjadi sistem internasional dapat dikaji dari proses transisi hingga perubahan arah interaksi untuk melihat bagaimana sistem internasional terbentuk melalui pandangan teori sistem kompleks.

Kata-kata kunci: Hubungan Internasional, Sistem Internasional, Teori Sistem Kompleks 


\section{Introduction}

It is very cut and dried to start this paper by proposing a statement that a little bit Cliché; however, talking about change or transformation international system is noteworthy because Contemporary International Relations (IR) as a discipline has sailed through a sea-changes in the world politics. The theme of change can easily be found in the rhetoric of political leaders, in media, as well as in the academic world. While it is not the paper objective to deny that changes or some forms of transformation have taken place or are taking place in the world, its task is only to describe the holistic understanding of the changing system of International Relations. ${ }^{1}$ IR as a discipline has been in the state of convolution amid sea-changes in the contemporary world. But, the inclination of many International Relations scholars to be allergic to theory and theorizing, on the one side of the fence, and their absorption with issues, on the other side of the fence, have led them to be simply reactive to this expansion. Some specialists (e.g. Goertzel 1994; Louth 2005; Mesjasz 1988, 2006) have suggested that in order to build more applicable explanations in social sciences, it is better to approach the phenomena through the lenses of complex systems theory, hoping that it would increase the understanding of the phenomena. It was even said that the complex system approach to the social science is a very essence of the "interdisciplinary" concept (Bar-Yam 1997). Accordingly, this paper aims to explain the dynamics of the international system using complex system theory. The core question to answer is how the dynamics of international system after the Cold War could be explained through the lens of complex system theory? This paper proposes a thesis statement that it could be explained by examining its structure of community system formation transition, when the community of nations becomes more complex and more pluralistic. Its manifestation as a set of pattern that became a system propel its phases of international relations and the interplay between systems of interest. Whereas the interplay of each system became a set of interactions in which the interests of two or more actors involved constitute an interesting system. It strings up the international

1 In this paper, the terminology 'International Relations' (with capital ' $I$ ' and ' $R$ ') refers to the academic discipline of international relations, while the term 'international relations' (with small ' $\mathrm{i}$ ' and ' $\mathrm{r}$ ') refers to the relations of international actors. See Anton Casian (2015) in his book 'The Concept and the Meaning of I (i) nternational R (r) elations'. 
system post-Cold War to interact with each other, not only as a pool of national interest or international interest anymore.

\section{Complex System Approach and International System}

Why apply a theory originated in physics in International Relations? As a social science scholar; the author to some extent is allergic to craft an analysis based on natural science methods, the limit to rationalize a natural science methodology is a solid obstacle in this paper. But complex system theory is not just another theory; it is more of a general perspective of analysis (Morel and Ramanujan 1999), a paradigm that brings new instruments into the conceptual toolkit of international relations.

At first, we have to understand what is system and system approach. The system is a unity of parts which are interconnected, located in a region, and had some driving forces; such as the State, political parties, agencies, etc. State, for example, is a collection of some elements, for instance some provinces are interconnected to form a country in which the driving force is the people. Lars Skyttner (2001) stated that a system must interconnect with other systems. If everything is good, it will establish harmony. It is assumed that each sub-system that existed have a symphony to shape the system and eventually, the system would be a kind of orchestra.

According to Rusadi Kantaprawira (1987), 'the system can be defined as a unit which is formed of several elements, or components, or part of each other in a latch-hook attachment and function. Each is cohesive with one another which means the aggregate of the unit maintained intact its existence. The system can be construed also as something higher than means, procedures, plans, schemes, procedures or methods. The system is a mechanism in a patterned manner and consistent, even the mechanism is often automatic'. It means that the system is everywhere around us and the world is the shed of systems. Launched by Bertalanffy (1968), the systemic approach swiftly became a preferred paradigm for many specialists, particularly because of its high adaptive modality to different situations, whether in technical matters or social life.

The isomorphism between technical and social systems, previously suggested by systemizes, brought the hope of surpassing the excessive 
disciplinary fragmentation of the sciences. Besides the analysis of social and natural entities, systemic thought allowed the design of highly predictable technical devices. As von Bertalanffy pointed out $(1968,38)$, general system theory had a purpose to highlight the tendency of integration between the natural and social sciences and to help the formulation of exact (i.e., mathematical) theories in non-physical fields of science. Moreover, it was expected that the theory would bring about the unification of the scientific disciplines. This idea was not entirely new; Comte hoped that industrial society will be led by scholars, while "social physics" (see Bagehot 2001) that emerged at the end of the 19th century, expressed the profound faith that humankind was following a road towards rationality. At its beginnings, the system theory seemed to be the most appropriate theoretical instrument of this progress (Laszlo 1972b).

This paper uses the term complex system to denote a set of interconnected and interdependent parts. Because the most important features of the complex systems are interconnectedness and emergence, i.e. the fact that the whole cannot be reduced to the sum of the components (Cîndea 2006). To approach international relations through the lenses of the complex systems paradigm, we must take a look at the older idea of level of analysis. The first time that this was used in international relations was by Kenneth N. Waltz (1959), who structured his explanatory theories of war on three separate levels: the individuals, the state, and the state's system. The number of level of analysis used as references by different scholars were in some cases even greater.

The most important thing is not to decompose a complex system into lower level complexities, or to increase the level on a scale of increasing complexity; instead, we should look at the logic of the interaction and the manner in which it reaches the emergence of the phenomena. In complex systems, from the living cell to the global social system, we can essentially identify the infinite levels of the organization. Of course, not all of them are relevant for the purpose of this paper. Although the human as an individual can be analytically decomposed into lower level complexities, for the purpose of the present analysis - the approach to peace and war we will consider the individual as an elementary unit of analysis. From the level of analysis' point of view, the emergence is the most important property of the complex systems. From one level 
of analysis to another, the functioning component parts are not sufficient to describe the behavior of the next level. An organ is not just the sum of a few thousands of cells, just as the functioning of every component cell, if taken separately, is not enough to explain the behavior of the whole tissue.

As Bar-Yam pointed out, the emergence is the property that forces us to approach complex systems with the prerequisite of multiscale complexity, that is, to assume complexity at all levels. In this sense, the complex system theory is a useful tool to bridge the micro-macro gap in social science (Goldspink and Kay 2004). One of the scholars that approached the society as a dynamic of complex systems, starts from the cell, then increases the aggregation to its highest level, which is the human civilization (Bar-Yam 1997). It means, the existence of International System experiences a reconfiguration until its system manifestation is no longer absolute as an environment for state activity only, but also with a dynamic condition; furthermore, it consists of a fluid entity that reveals a myriad system. The complex system approach is situated at the border between the nomothetic and idiographic science. In international relations, this approach is placed at the boundary between constructivism and structural realism, contributing to the agent-structure debate in international relations (see Buzan et al. 1993). In the context of international politics, the conception of "system" conceptually has been used mainly in two ways, international system, and world system(s). First, the term "international system" is a concept for analysis or description of international politics or relations, but therein lies a sense of prescription for diplomatic or military action too. Used as an analytical term, it is predicated upon a definite notion of system. But it is not necessarily so when it is used to describe situations of international relations at a given time. Second, the term "world system(s)" is a concept with which to analyze or describe mainly politico-economic global situations, while its implications for political action are derived but only indirectly (Hatsuse, 2010).

When we foresee to bring the probability of this contrast into international relations, it is important to utilize argument developed by Hedley Bull (1977) in elaborating on the distinction between international system and society. As to the former, he defines: $a$ system of states (or international system) is formed when two or more states have sufficient contact between them, and have sufficient 
impact on one another's decisions, to cause them to behave-at least in some measure-as parts of a whole. This corresponds very well to the first definition of system stated before. Realist (Kaplan, 1957; Morgenthau, 1960) and Neorealist (Gilpin, 1981; Waltz, 1979), untroubled by the seasonal "idealist" offensive that punctuate international debates, and empowered by positivist and exclusively materialist philosophies of science have been reluctant to engage in ontological and epistemological polemics. Both prefer to elaborate International Relations as simple behavioral response to the forces of physics that act on material objects from the outside. But, according to Jervis $(2017,6)$, "we are dealing with a system when (a) a set of units or elements is interconnected so that changes in some elements or their relations produce changes in other parts of the system, and (b) the entire system exhibits properties and behaviors that are different from those of the parts." A system's key properties are, therefore, interconnectedness and non-additivity. Departing from this context, this paper underlies its analysis not only based on positivist approach, but also reflective approach. ${ }^{2}$

\section{Systems And International Relations}

In general terms, and also in terms of international relations, "system" refers to a group of parts or units whose interactions are significant enough to justify seeing them in some sense as a coherent set. A

2 Positivism has been the dominant epistemological point of view in IR; according to Steve Smith and Patricia Owens (2005), positivism creates knowledge supported by four foundational assumptions. Firstly, methodologies which apply in the scientific world can be assumed to perform much the same in the non-scientific world; they refer to this as the 'unity of science'. Secondly, assumption that uphold a clear delineation between values and facts as well as, perhaps most importantly, the belief that facts remain neutral between various theories. Thirdly, the natural and social worlds have regularities which can be uncovered by theories, and therefore the same process by which a scientist approaches the natural world can also be used to investigate the social world. Lastly, there is an assumption that the way to determine the truth of theories or statements is through the utilization of these neutral facts in conjunction with the falsification principle or the correspondence theory of truth, or in other words, an empirical process for truth determination. Whilst, reflectivism, also known as post-positivism or anti-positivism, grew in popularity within IR during the 1980s and burst into the mainstream when positivism failed to predict the end of the Cold War (Monteiro and Ruby 2009). 
group of states forms an international system when "the behavior of each is a necessary factor in the calculations of the others" (Bull and Watson 1984, 1). It means a system in IR is the constellation of the state that interacts with each other. This is a classic definition that in some extent still maintains its capability to explain the interaction between States and how they conduct their role in an international milieu.

One of the first thinkers to craft systems concept in IR was Morton Kaplan. Kaplan's international system consisted of states interacting in six possible patterns or structures (Kaplan 1957): (1) Multipolar: a balance of power arrangement which is literally a billiard ball model; (2) Loose Bipolar: two main opposing spheres with satellites and varying degrees of adherence to either side; (3) Tight bipolar: like the previous ones, but with clear allegiances to one sphere; (4) Universal: a confederation of all groups controlled by one government; (5) Hierarchical: significant groupings that are functional rather than territorial, also a federation; (6) Unit veto: each group can destroy all others, so there is mutually assured destruction (MAD). Kaplan was mainly interested in the intrinsic or relative stability of each type of systems. Interestingly, historical examples exist for only two structures, the balance of power of the 18th and 19th centuries, and the post-World War II's loose bipolar system. (Flood et al., 2013) In this approach, Kaplan is trying to answer under what conditions system transformation would occur. Weltman (1973) criticized Kaplan's for the lack of operational in his international system analysis. He said that:

Few of Kaplan's 'essential rules' for his six international systems have turned on the examination to flow in a logically necessary fashion from his regulatory hypotheses. Those tend to be tautological or incapable of operational verification and falsification, or both ... Given the nonoperational or tautological nature of the bulk of the 'essential rules' of his systems, it follows that Kaplan's conclusions concerning systemic stability and transformation are not compelling.

However, Kaplan's international systems approach has been recognized by Mithcell (1978) as "....by far the most intellectually rigorous of the earlier works on international systems analysis." For the sake of having a solid framework to analyze international 
systems, this paper takes Kaplan's international systems as guidance to achieve the goal of this paper. Kaplan proposes a definition that international system is a state-system. Kaplan divides the level of state in a sub-system. In this designation, foreign policy and environment define how the interaction and regulation in the level of state. International systems according to Kaplan at the beginning of world politics is represented infamous a billiard ball model, where NationState is assumed as a black box with the shell of sovereignty. In this model, nation-state is the main actor that interacts with each other. According to Realist's view, the notion about how international system change through the shift of actor behavior is to fulfill interest and distribute power (it is usually determined by war, economic development, and politics). This is the basic understanding that layered multi polar international system. This is the reason why balance of power became the prime concept that represents world politics in this model.

\section{Figure 1}

\section{Billiard Ball Model of World Politics}

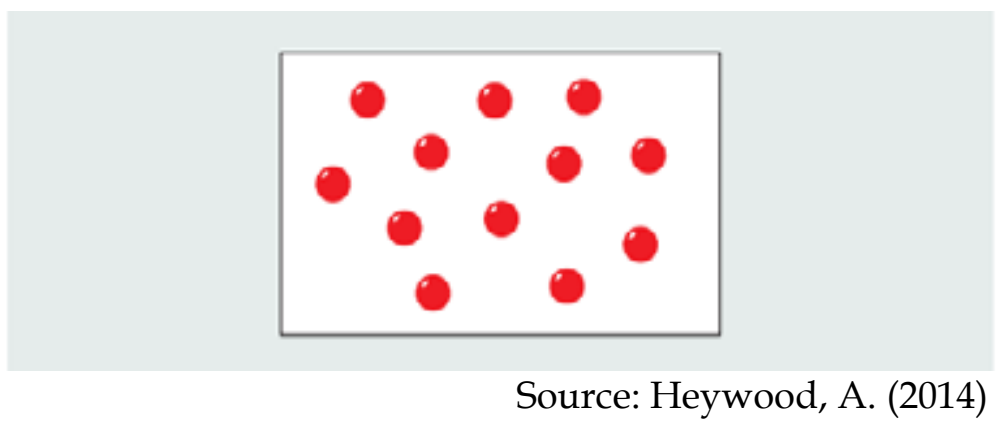

Then Cold War elevated a particular reconfiguration to the international system; the nature of Cold War was represented by two super-power who were shadow-boxing to gain influence in world politics (US and USSR) and implicated how state-system interacts at that time. Whereby, the international system became bipolar because the world is bifurcated to two-polars that exercise their power. In this international system's model, some satellite states which were usually called 'proxy' emerged. Vietnam war and Korea War are the utmost example of Proxy war that occurs in world history. Since World War I to World War II and Cold War, nationstates and dynamic of war become central to the discussion of IR. The framework that international system is a state-system which is 
prominent in this era. Almost no IR discussion that takes a subject out from Nation-State as unit analysis and war is the central issues at that time. The long Cold War finally reach its end by the collapse of Soviet Union; the collapse of the Soviet Union provided a historic opportunity to examine how key states respond to large-scale change in the international system. Between the fall of the Berlin Wall in November 1989 and the aborted August coup that preceded the demise of the Soviet Union in 1991, the international system witnessed the disintegration of the bipolar power that characterized the post-1945 international order (Harrison 2004).

\section{The Relation Become A Complex Interaction}

A community is based on relationships in which the use of force is deterred, and such deterrence is a necessary condition for a community to exist. A relationship in which unlimited violence was permitted would be inconsistent with the very concept of a community (Hirose 2003). This conceptualization, which was developed to describe domestic societies, is also useful in considering whether present-day international relations comprises of a set of relationships or whether they have begun to take on the structure of the community. The principle of the outlawry of war evolved as a synthesis of elements drawn from two competing views of war over the course of several centuries, and this principle has now begun to be effective. The minimum condition, that is logically necessary for a community to exist can, therefore, be said to actually exist in international relations. In this sense, the nations of the contemporary world, which are making a serious effort to outlaw war, can be conceived of as a community. However, relationships based on the use of force, which have long characterized international relations, still exist. Actual international relations are thus a complex system in which an old order and a new order coexist and compete. The old order can be described as a set of relationships based on the use of force, i.e., an interesting system; the new order can be described as a set of relationships in which the use of force is deterred, i.e., a role system. (Hirose 2003, 181). 


\section{Figures 2 The Phases of International Relations}

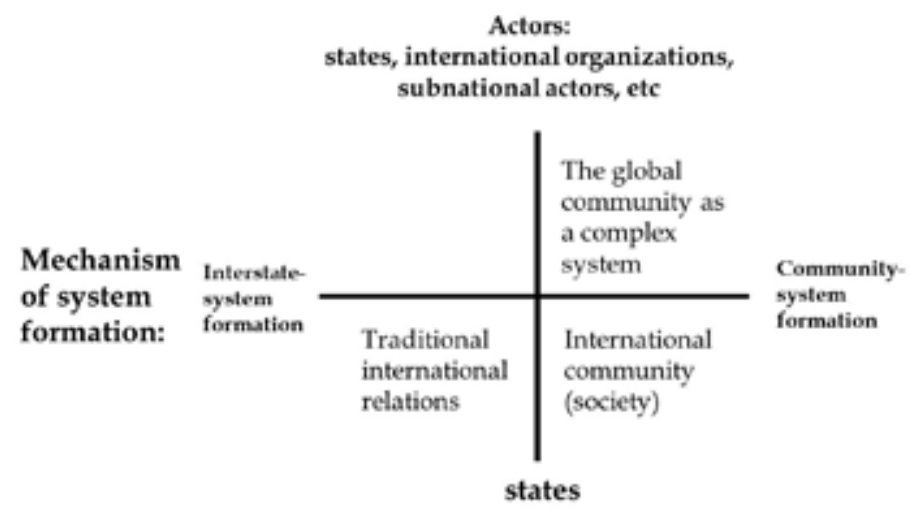

Source: Hirose, K. (2003)

The characteristics of this system become clearer, if their positions are plotted on two coordinate axes (Figures.2). The horizontal axis indicates whether interstate-system formation or community system formation is taking place. In the traditional view, the order in international relations is thought to consist of the aggregate of direct interactions between sovereign states (interstate-system formation); national sovereignty is assumed, and the pursuit of national interests is taken to be a self-evident reason for action. In contrast to this, this paper's vantage point calls for community-system formation regards international relations as constituting a single entity, or community; this approach does not separate international relationships into their components, but instead tries to understand their order within a framework of international organizations or institutions such as the United Nations. This institutional approach has their momentum after the Cold War has ended and the world starts to seek a new conceptual framework to craft the world without war and human abuse. Interstate-system formation is the basic model employed in the study of international relations; in reality, however, in every era, interstate-system formation has coexisted with the community system formation. It is only their relative weights that have varied over different times and between different geographical ranges of societies or communities.

Aspects of community system formation are revealed at transition points, both between eras and at the smaller transition points within 
each era, when the community of nations becomes more complex and more pluralistic. In reality, international relations are no longer limited to an aggregation of relations between states. Actors at various levels have appeared in the international arena, interacting with one another both horizontally and vertically and continuing building mutually dependent relationships. These relationships have now reached the point where they can be thought of as part of a single community. In this set of dense social interaction; IR found its limit of the classical IR tradition understanding about international issues, this limit push IR to the action of reassessing the theoretical framework of its science; it starts by opening the black box of nationstate and start to see the world as a single community that consists various actors (state, non-state organization even an individual) which pose a serious potency to became an issue

Figure 3

Level of Interest as a System

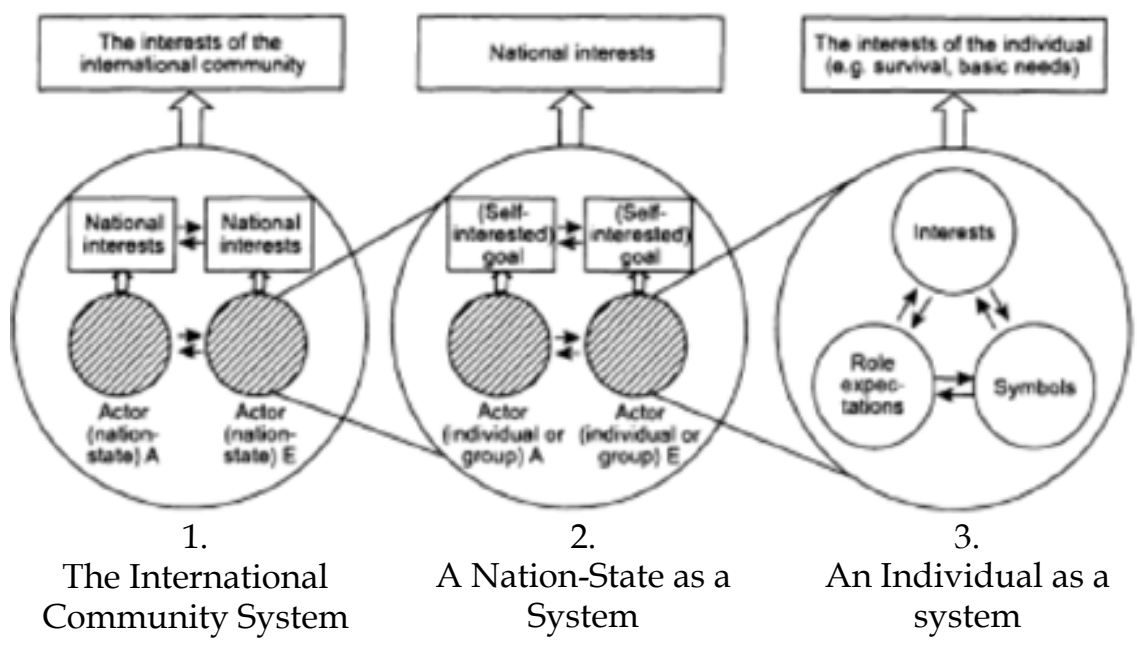

Source: Hirose, K. (2003)

The picture above portrays how the international system post-Cold War interacts with each other. We can no longer see the international system only as a pool of national interest or international interest anymore, but it is a pool of interest. The choice of what to regard as a system and what to regard as its elements and the actors, depends on an investigator's purpose. However, the most basic behavior is to promote the continual existence of the actor. Let us regard one's 
own survival as an interest, and regard behavior that serves to promote one's own survival as interest-oriented behavior. For the purposes of conceptualizing interest-oriented behavior, let's assume that a particular actor's interests are endogenous to that actor and they exist in isolation from the whole where that actor is situated (in the case of a nation, the international community). According to Kazuko Hirose (2003), this assumption can justifiably be made because the actors are 'black boxes,' or units whose internal functions and mechanisms are hidden from the observer, as is shown by the shaded circles in figures 3 .

Thereafter, if one wanted to know how national interests evolve, it is important to apprehend the nation itself as a system and to ask what (explicit or implicit) goal has been established in order to determine that system's survival. This would lead our lens of analysis to explore the internal structure of the nation-state as a system. The processes by which conflict is resolved among the often opposing interests of the individuals and interest groups that make up a nation would have to be considered, together with the nature of the overall national interests that emerge as a result of those processes and that are asserted in relation to the external world. two nation-states (actors) in the international community are treated as black boxes (as indicated by the diagonal lines). In Figure. 3 the internal structure of a nation-state is taken as a system, while two individuals or groups that are actors in that system are treated as black boxes. (It should be remembered that an individual is also a complex actor whose behaviors are variously motivated, and thus one can also examine, what an individual is like internally as a system. Therefore, it is necessary to set limits here as to what one regards as a system and what one regards as an actor in order to avoid confusion in the discussion that follows. If a state's actions are performed in the context of its relationships with other states; these other states can also basically be assumed to be acting in their own national interests (Hirose 2003,52). Thus, a relationship between two states often is where national interests collide. It means that the international community interest as a system consists of a set of interactions between two or more actors with their respective interests which are involved to constitute a system of interest. It causes the manifestation of international system after the ruination of the bipolar system became more complicated and difficult to grasp. 


\section{Conclusion: The opportunity for Interdisciplinarity approach}

This paper already explains its vantage point; through the lens of complex system theory, we could explain the dynamic of the international system that represents the existence of international relations among nation-state. This paper analysis argues that community system formation is revealed at transition points, when the community of nations becomes more complex and more pluralistic. Its manifestation as a set of pattern that became a system could be traced from its phases of international relations that explain a particular mechanism of systems formation. Whereas, the interplay of each system could be apprehended through the level of interest of it. Whereby, each system related to each other and became a set of interactions where the actors' interests constitute an interesting system. It strings up the international system postCold War to interact with each other, not only as a pool of national interest or international interest anymore, but also as a pool of interest. The nation-state, the main reference point of the dominant paradigm in the international relations, is now seen that state borders are becoming more and more permeable, almost to their dissolution, and military power cannot by itself secure a state's survival. Globalization, reflexivity of the object studied, and the social indeterminism principle is the main arguments in favor of a complex system approach to the international reality. Thereafter, if one wanted to know how national interests evolve, it is important to apprehend the nation itself as a system and to ask what (explicit or implicit) goal has been established in order to determine that system's survival. This would lead our lens of analysis to explore the internal structure of the nation-state as a system. This is the new challenge for the next IR thinkers and it also an intriguing opportunity for those who care about how the world interacts with a system called international system. It is an effort to systematically expand IR research towards a large number of disciplines and fields of study while building on past interdisciplinary approaches and accepting the coterminous presence of disciplinary IR (Pami Aalto et al. 2011). 


\section{Reference}

Aalto, Pami, Vilho Harle, and Sami Moisio, eds, 2011, International studies: interdisciplinary approaches. Palgrave Macmillan.

Bagehot, Walter, 2001 [1872], Physics and Politics or Thoughts on the Application of the Principles of "Natural Selection" and "Inheritance" to Political Society. Kitchener: Batoche Books.

Bar-Yam, Yaneer, 1997, Dynamics of Complex Systems. Reading: Addison-Wesley

Bernstein, Steven et al. 2000, "God Gave Physics the Easy Problems: Adopting Social Science to an Unpredictable World". European Journal of International Relations, Vol. 6, No. 1, pp. 43-76.

Bertalanffy, Ludwig von, 1998, General System Theory. New York: George Braziller.

Bull H. 1977. The Anarchical Society. London: Macmillan. pp. 335 (A brilliant discussion on the basic features of international relations and society).

Buzan, Barry, 1983, People, State and Fear. The National Security Problem in the International Relations. Massachusetts: Harvard University Press.

Buzan, Barry and Charles Jones and Richard Little, 1993, The Logic of Anarchy. Neorealism to Structural Realism. New York: Columbia University Press.

Buzan, Barry, 2014. An introduction to the English school of international relations: the societal approach. John Wiley \& Sons.

Cîndea, Ion, 2006. "Complex Systems-New Conceptual Tools for International Relations." New Perspectives. Interdisciplinary Journal of Central \& East European Politics and International Relations 26, 46-68.

Flood, Robert L. and Ewart Carson, 2013. Dealing with complexity: an introduction to the theory and application of systems science. Springer Science \& Business Media.

Gilpin, R. 1981. War and change in the international system. Princeton: Princeton UniversityPress.

Goldspink, Chris and Robert Kay, 2003. "Organization as SelfOrganizing and Sustaining Systems: A Complex and Autopoietic Systems Perspective". International Journal of General Systems, Vol. 32, No. 5, Oct., pp. 459-474.

Goldspink, Chris and Robert Kay, 2004, "Bridging the micro-macro divide: A new basis for social science". Human Relations, Vol. 57, No. 5, pp. 597-618. 
Goertzel, Ben, 1994, Chaotic Logic. Language, Thought and Reality From the Perspective of Complex Systems Science. New York: Plenum Press.

Hatsuse, R, 2010. International System. International Sustainable Development Law-Volume III, 22.

Heywood, Andrew, 2011. Global Politics, Palgrave Macmillan, Palgrave Foundation Series.

Hirose, Kazuko, 2003. A social theory of international law: international relations as a complex system. Vol. 10. Martinus Nijhoff Publishers.

Jervis, R. 2017. Perception and misperception in international politics. Princeton University Press.

Kaplan, Morton A, 1957, "Balance of Power, Bipolarity and Other Models of International Systems". The American Political Science Review, Vol. 51, No. 3, pp. 684-695.

Kaplan, M. 1957. System and process in international relations. New York, 17.

Kantaprawira, Rusadi, 1987. Aplikasi pendekatan sistem dalam ilmuilmu sosial. Bunda Karya.

Laszlo, Ervin, 1972a, Introduction to Systems Philosophy. Towards a New Paradigm of Contemporary Thought. New York: Harper \& Row, Publishers.

Laszlo, Ervin (Ed.), 1972b, The Relevance of General Systems Theory. New York: George Braziller.

Louth, Jonathan, 2005, "The Complexity of Globalization: Moving Beyond Theoretical Uncertainty". Refereed paper presented to the Australasian Political Studies Association Conference, University of Otago, New Zealand.

Mesjasz, Czeslaw, 1988, "Application of System Modelling in Peace Research". Journal of Peace Research, Vol. 25, No. 3, pp. 291-334.

Mesjasz, Czeslaw, 2006, "Complex system studies and the concepts of security". Kybernetes, Vol. 35, Issue 3 / 4, pp. 471-488.

Mitchell, C. R., 1978. Systems theory in international relations. In Groom, A. J. R., and Mitchell, C. R. (eds.), International Relations Theory, A Bibliography, pp. 78-103. London: Frances Pinter.

Monteiro, N. P. and Ruby, K. G, 2009, 'IR and the false promise of philosophical foundations'. International Theory, 1(1), pp. 15-48.

Morel, Benoit and Rangajai Ramanujan, 1999. “Through the Looking Glass of Complexity: The Dynamics of Organizations as Adaptive and Evolving Systems". Organization Science, Vol. 10, No. 3.

Morgenthau, H. J. 1967. Politics Among Nations: The Struggle Fo Power 
and Peace. New York: Knopf

Skyttner, Lars, 2001. General systems theory: ideas \& applications. World Scientific.

Skyttner, Lars, 2005. General systems theory: problems, perspectives, practice. World scientific.

Smith, S. and Owens, P., 2005, 'Alternative approaches to international theory'. In: J. Baylis and S. Smith, eds., 2005, The Globalization of World Politics. Oxford: Oxford University Press, pp. 271-293.

Urry, John, 2002. "The Global Complexities of September 11th". Theory, Culture \& Society, Vol. 19, No. 2, pp. 57-69.

Watson, Adam, and Hedley Bull, 1984. “The expansion of international society." The expansion of international society.

Waltz, Kenneth N., 1959.Man, the State and War. A Theoretical Analysis. New York: Columbia University Press.

Waltz, Kenneth N., 1979.Theory of International Politics. Reading: Addison-Wesley.

Weltman, J. J., 1973. Systems Theory in International Relations. Lexington, Mass.: D. C. Heath. 